\title{
Peptidoglycan-bound Polysaccharide Associated with Resistance of Rhizobium loti Strain NZP2037 to Lotus pedunculatus Root Flavolan
}

\author{
By WILliaM T. JONES, * PAULINE E. MACDONALD, \\ STEPHEN D. JONES AND CLIVE E. PANKHURST $\dagger$ \\ Applied Biochemistry Division, Department of Scientific and Industrial Research, \\ Palmerston North, New Zealand
}

(Received 30 December 1986; revised 13 April 1987)

\begin{abstract}
Resistance of Rhizobium loti strain NZP2037 to the prodelphinidin-rich flavolan (condensed tannin) present in the roots of Lotus pedunculatus was associated with the presence of a peptidoglycan-bound flavolan-binding polysaccharide (FBP) in the outer cell membrane of this bacterium. The outer cell membrane of a flavolan-sensitive strain, NZP2213, did not contain this polysaccharide. FBP was extractable in highest concentration from NZP2037 cells during exponential growth of the bacteria. This correlated with exponential-phase cells of NZP2037 showing maximum resistance to flavolan. When added to cultures of NZP2213, FBP afforded a concentration-dependent protection of this strain to the bactericidal effect of the flavolan. ELISA and immunogold labelling of Rhizobium cells using FBP-specific antibodies confirmed the presence of FBP on the outer cell surface of NZP2037 cells and its absence from NZP2213 cells. Co-inoculation of $L$. pedunculatus with antibiotic-resistant mutants of NZP2037 and NZP2213 resulted in the formation of $\mathrm{N}_{2}$-fixing nodules containing both strains.
\end{abstract}

\section{INTRODUCTION}

The ability of certain strains of Rhizobium loti (Jarvis et al., 1982) to form effective $\mathrm{N}_{2}$-fixing $\left(\mathrm{Nod}^{+} \mathrm{Fix}^{+}\right)$nodules on Lotus species is correlated with their 'in vitro' sensitivity to flavolans (condensed tannins) present in high concentration in the roots of this legume (Pankhurst \& Jones, 1979). A representative strain, NZP2037, which forms $\mathrm{Nod}^{+} \mathrm{Fix}^{+}$nodules on Lotus pedunculatus, was found to be four times more tolerant ('in vitro') of the flavolan extracted from the roots of this Lotus species than was strain NZP2213 which forms ineffective $\left(\mathrm{Nod}^{+} \mathrm{Fix}^{-}\right)$ nodules (Pankhurst et al., 1979; Pankhurst \& Jones, 1979). The Nod ${ }^{+}$Fix $^{-}$nodules formed by NZP2213 on L. pedunculatus are tumour-like and contain no intracellular rhizobia (Pankhurst et al., 1979). The ability of strain NZP2037 to tolerate higher concentrations of the flavolan 'in vitro' was associated with the capacity of the outer cell membrane of NZP2037 bacteria to bind more flavolan molecules than the outer cell membrane of NZP2213 bacteria (Pankhurst \& Jones, 1979; Pankhurst et al., 1982).

The initial Rhizobium-flavolan interaction is bacteriostatic. This is associated with cessation of growth and binding of flavolan molecules to the outer cell membrane of the Rhizobium cells. Subsequently the cells become swollen, irregularly shaped, and lose viability, possibly because cell division is inhibited (Pankhurst et al., 1982).

In order to define further the nature of the flavolan resistance of strain NZP2037, we have identified surface components of NZP2037 and NZP2213 cells that bind flavolan molecules.

† Present address: CSIRO, Division of Soils, Private Bag no. 2, Glen Osmond, Adelaide, South Australia 5064, Australia.

Abbreviations: FBP, flavolan-binding polysaccharide; PBS, phosphate-buffered saline; TBS, Tris-buffered saline. 
Flavolans can cross-link with protein and polysaccharide molecules to form large aggregates which are solubilized but not dissociated by SDS (Jones \& Mangan, 1977). Thus, molecules reacting with flavolans can be identified by their inability to enter polyacrylamide gels or by their reduced mobility due to aggregation. Using this approach we show that flavolan binds in small amounts to a lipoprotein component of the outer cell membrane of both strains, but in large amounts to a strain-specific peptidoglycan-bound polysaccharide component of NZP2037 cells.

\section{METHODS}

Organisms and growth. Rhizobium loti strains NZP2037, NZP2213 and PN236 [a Nod ${ }^{+}$Fix $^{-}$Tn5-induced mutant of NZP2037 (Chua et al., 1985)] were maintained on a mannitol/salts/yeast extract $\left(\mathbf{M}^{+}\right)$medium (Pankhurst, 1977). A modified form of this medium $\left[\mathrm{M}^{-}\right.$, with yeast extract replaced with $\left(\mathrm{g} \mathrm{l}^{-1}\right)$ sodium glutamate $(1.0)$, thiamin hydrochloride $(0.0005)$, biotin $(0.005)$ and calcium panthothenate $(0.01)]$ was used as a minimal medium for growing the rhizobia. Rhizobium growth in this medium was followed by measurement of optical density at $600 \mathrm{~nm}$. Cell numbers were calculated from a graph of optical density values versus log total cell number [determined by direct counts using a Thoma (Gallenkamp) counting chamber]. Nodulation tests were done on Lotus pedunculatus Cav. 'Grasslands Maku' and $L$. tenuis Waldst. et Kit with plants grown under axenic culture conditions in test tubes (Pankhurst, 1981). A spontaneous spectinomycin-resistant mutant of NZP2037 (strain PN4001) and a spontaneous streptomycin-resistant mutant of NZP2213 (strain PN4115) were used in "coinoculation' experiments where it was necessary to identify the two strains. These mutants were identical to their respective parent strains in both their growth and nodulation characteristics. Rhizobia isolated from nodules (Pankhurst, 1981) were streaked onto $\mathrm{M}^{-}$agar plates containing, where appropriate, spectinomycin $\left(20 \mu \mathrm{g} \mathrm{ml}^{-1}\right)$ or streptomycin $\left(250 \mu \mathrm{g} \mathrm{ml}^{-1}\right)$ for strain identification.

Assay for testing the effect of flavolans on the growth of Rhizobium. Culture conditions and assay procedures for testing the sensitivity of rhizobia to flavolans in liquid culture were as described by Pankhurst $e t$ al. (1982). The effect of a putative flavolan-binding polysaccharide on the Rhizobium-flavolan interaction was determined as

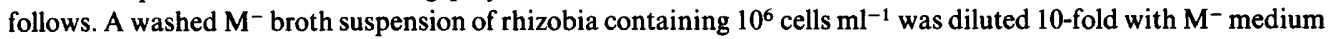
containing flavolan and polysaccharide and incubated with shaking ( 100 r.p.m.) at $28^{\circ} \mathrm{C}$. After $24 \mathrm{~h}$, samples were removed and the number of viable bacteria determined by dilution plating into $\mathrm{M}^{-}$agar medium.

Identification of flavolan-binding components from Rhizobium cells. Rhizobia grown in $\mathbf{M}^{-}$broth to midexponential phase were harvested by centrifugation $\left(10 \mathrm{~min}\right.$ at $\left.20000 \mathrm{~g}, 4^{\circ} \mathrm{C}\right)$, washed twice with $0 \cdot 1 \mathrm{M}$-potassium phosphate buffer, $\mathrm{pH} 7 \cdot 2$, and resuspended in the same buffer to give $10^{11}$ cells $\mathrm{ml}^{-1}$ (total cell count). A portion of this suspension was then mixed rapidly with an equal volume of phosphate buffer containing flavolan $\left(500 \mu \mathrm{g} \mathrm{ml}^{-1}\right)$. After mixing, the suspension was incubated at $28^{\circ} \mathrm{C}$ for $4 \mathrm{~h}$. After incubation the bacterial cells were collected by centrifugation and washed once with phosphate buffer containing $1 \%(\mathrm{w} / \mathrm{v})$ polyvinylpyrrolidone $\left(M_{\mathrm{r}} 10000\right.$; Sigma), and then resuspended with the aid of brief sonication (15 s; MSE Ultrasonic Disintegrator) in $0.125 \mathrm{M}$-Tris $/ \mathrm{HCl}$ buffer, $\mathrm{pH} 6.8$, containing $1 \%(\mathrm{w} / \mathrm{v}) \mathrm{SDS}$ and $5 \%(\mathrm{v} / \mathrm{v}) 2$-mercaptoethanol. The suspension was then heated in a boiling water bath for $5 \mathrm{~min}$ and centrifuged at $40000 \mathrm{~g}$ for $1 \mathrm{~h}$. The pellet was resuspended in fresh extraction buffer and the process of extraction repeated a further three times. The supernatants from each extraction were then combined and stored for electrophoretic analysis. The residue, consisting of Rhizobium cell envelopes, was washed three times with $0.125 \mathrm{M}-\mathrm{Tris} / \mathrm{HCl}$ buffer, $\mathrm{pH} 6.8$, and then resuspended in the same buffer containing $20 \mu \mathrm{g}$ lysozyme $\mathrm{ml}^{-1}$ (39000 units $\mathrm{mg}^{-1}$; Sigma) and $370 \mu \mathrm{g}$ EDTA $\mathrm{ml}^{-1}$ and incubated (with shaking, 100 r.p.m.) for $12 \mathrm{~h}$ at $28^{\circ} \mathrm{C}$. After incubation the suspension was centrifuged at $40000 \mathrm{~g}$ for $1 \mathrm{~h}$. The pellet was washed twice with Tris buffer and then extracted three times with Tris/SDS/2mercaptoethanol, as above. The combined supernatants from these extracts were retained. The final residue was washed twice with Tris buffer and then resuspended in this buffer. Residues and SDS extracts were analysed for flavolans (see below). Soluble extracts were examined by SDS-PAGE for loss of components from flavolan-treated cells compared to untreated cells.

Isolation of a flavolan-binding polysaccharide (FBP) from NZP2037 cells. NZP2037 cells grown to midexponential phase in $\mathbf{M}^{-}$media were extracted exhaustively with SDS buffer to solubilize membrane and soluble molecules and the residual cell envelopes treated with lysozvme as described above. The residue obtained after the lysozyme treatment was extracted with phenol/water (Westphal \& Jann, 1965) to extract the polysaccharide. The water layer was extracted 10 times with an equal volume of diethyl ether, dialysed (twice) against distilled water, centrifuged $(48000 \mathrm{~g}$ for $10 \mathrm{~min}$ ) and freeze-dried. The freeze-dried material was shown by PAGE to contain the FBP as the major constituent $(>90 \%)$ and to be free of protein.

Analysis of flavolans and binding of flavolan to FBP. Flavolan was prepared from the roots of $L$.pedunculatus as an off-white polymer (prodelphinidin : procyanidin ratio $77: 23$ ) as described by Jones et al. (1976). Free flavolan was measured by the vanillin/ $\mathrm{HCl}$ method (Broadhurst \& Jones, 1978). Flavolan bound to bacterial cells or membranes or contained within SDS extracts was measured as anthocyanidin after boiling in butanol/ $\mathrm{HCl}$ (Jones et al., 1976). 
To study the binding of flavolan to FBP, $50 \mu \mathrm{l}$ of FBP $\left(1 \mathrm{mg} \mathrm{ml}^{-1}\right.$ in distilled water) or $50 \mu$ l of water (control) were added to $50 \mu \mathrm{l}$ of water containing flavolan $(0$ to $1000 \mu \mathrm{g})$ and incubated at $20^{\circ} \mathrm{C}$ for $1 \mathrm{~h}$. After this incubation $0.9 \mathrm{ml}$ of water was added to each sample which was then centrifuged $(48000 \mathrm{~g}, 10 \mathrm{~min})$. A sample $(0.5 \mathrm{ml})$ of the supernatant was then analysed for flavolan. Bound flavolan was estimated as the difference between the flavolan content of samples with or without added FBP.

Measurement of FBP and a flavolan-binding lipoprotein in NZP2037 and NZP2213 cells at different stages of growth. To quantify the amount of FBP and a flavolan-binding lipoprotein produced by Rhizobium cells at different stages of growth small samples of cells (about $5 \times 10^{9}$ ) were first extracted with SDS and treated with lysozyme as described above. SDS extracts of the lysozyme-treated cells were then electrophoresed on $15 \%(w / v)$ polyacrylamide gels. The polysaccharide was stained with periodic acid/Schiff's reagent and the lipoprotein stained with Coomassie blue. The gels were then cut into strips and the optical density of the stained bands measured using a Gilson gel scanner attached to a Beckman DU spectrophotometer. The optical density (peak height) of the polysaccharide band was measured at $500 \mathrm{~nm}$ and the optical density of the major 'lipoprotein' band $\left(M_{\mathrm{r}} 44000\right.$; Fig. 1) was measured at $595 \mathrm{~nm}$.

Gel electrophoresis. SDS extracts were electrophoresed through $15 \%$ polyacrylamide gels according to Laemmli (1970). Proteins were stained with 0.25\% (w/v) Coomassie blue R-250 (Sigma) in methanol/water/acetic acid $(4: 4: 1$, by vol.) and destained in the same solvent. Polysaccharides were stained with periodic acid/Schiffs reagent and basic fuchsin (Zacharius et al., 1969) and lipid with Sudan black.

Western blotting. After PAGE, proteins and polysaccharides were transferred to nitrocellulose (Towbin et al., 1979), using a Tris $(0.125 \mathrm{M})$ /glycine $(0.04 \mathrm{M})$ buffer, $\mathrm{pH} 8 \cdot 3$, containing $10 \%(\mathrm{v} / \mathrm{v})$ methanol and $0.003 \%(\mathrm{w} / \mathrm{v})$ SDS, overnight at $70 \mathrm{~V}$ and $10{ }^{\circ} \mathrm{C}$. The nitrocellulose was stained for protein with $0.1 \%(\mathrm{w} / \mathrm{v})$ Amido black in methanol/water/acetic acid $(68: 25: 7$, by vol. $)$ and destained in the same solvent. For probing with antibodies, the nitrocellulose was blocked with $3 \%$ (w/v) BSA (Fraction V; Sigma) in Tris-buffered saline (TBS; $50 \mathrm{mm-Tris,}$ $0.8 \%(w / v) ~ N a C l, p H ~ 7.5)$ for $1 \mathrm{~h}$ at $37^{\circ} \mathrm{C}$. The nitrocellulose was probed with antibodies from test and preimmune sera in dilution buffer (TBS containing 3\%,w/v, BSA and $0.05 \%, \mathrm{v} / \mathrm{v}$, Tween 20 ) for $1 \mathrm{~h}$ at $37{ }^{\circ} \mathrm{C}$, washed four times for $5 \mathrm{~min}$ in wash buffer (TBS containing 0.05\% Tween 20) and probed with alkaline-phosphataselabelled anti-(rabbit IgG) (Sigma) (diluted 1000-fold in dilution buffer) for $1 \mathrm{~h}$ at $20^{\circ} \mathrm{C}$. The nitrocellulose was then washed three times for $5 \mathrm{~min}$ in wash buffer, once in $0.2 \mathrm{M}$-Tris/ $\mathrm{HCl}, \mathrm{pH} 8.2$, and the phosphatase activity developed in $0.2 \mathrm{M}-\mathrm{Tris} / \mathrm{HCl}$, pH 8.2, containing Napthol AS-MX $\left(0.4 \mathrm{mg} \mathrm{ml}^{-1}\right.$; Sigma) and Fast violet B salt $\left(2.5 \mathrm{mg} \mathrm{ml}^{-1}\right.$; Sigma). The nitrocellulose was then washed with distilled water to stop the reaction and air-dried.

Gel filtration. Gel filtration was done on Ultragel ACA 22 (LKB) in $25 \mathrm{mM}-\mathrm{Tris} / \mathrm{HCl}, \mathrm{pH} 7 \cdot 4$, containing $1 \%$ SDS. The column size was $100 \mathrm{~cm} \times 1.6 \mathrm{~mm}$ and the flow rate $7 \mathrm{ml} \mathrm{h}^{-1}$. The column was calibrated using the following proteins: bovine salivary band 4 protein, $M_{\mathrm{r}} 70000$ (Jones et al., 1982); BSA, $M_{\mathrm{r}} 65000$; ovalbumin, $M_{\mathrm{r}} 43000$; carbonic anhydrase, $M_{\mathrm{r}} 29000$ and lysozyme, $M_{\mathrm{r}} 14000$. The void volume of the column was determined using dextran blue (Pharmacia). The fraction size collected was $0.6 \mathrm{ml}$. $M_{r}$ values of FBP and a flavolan-binding lipoprotein were determined from the relationship between $\mathrm{K}_{\mathrm{av}}$ and $\log M_{\mathrm{r}}$.

Production of antibody to FBP. Purified FBP $(500 \mu \mathrm{g})$ was dissolved in sample buffer (Laemmli, 1970) and separated on a $15 \%$ polyacrylamide gel containing a single well. After separation, two columns of holes $(1 \mathrm{~cm}$ apart) were punched down both sides of the gel $(1 \mathrm{~cm}$ from the edge of the sample well into the sample region) and the gel sliced vertically through the holes. These two gel slices were then stained for polysaccharide as described above. The stained slices were then lined up with the unstained portion of the gel by matching the holes to locate the FBP. The region of the gel containing the FBP was dissected, homogenized into phosphate-buffered saline [PBS; $80 \mathrm{~g} \mathrm{NaCl}, 11.5 \mathrm{~g} \mathrm{Na}_{2} \mathrm{HPO}_{4}, 2.0 \mathrm{~g} \mathrm{KH}_{2} \mathrm{PO}_{4}\left(1^{-1}\right)$ ] using a glass homogenizer and the suspension injected subcutaneously into New Zealand White rabbits at 2 week intervals (Harboe \& Ingild, 1974). The IgG fraction of the collected serum was purified by ammonium sulphate precipitation followed by ion exchange chromatography (Harboe \& Ingild, 1974). Specificity of the antibody was tested by Western blot analysis using pre- and postlysozyme SDS extracts of mid-exponential phase NZP2037 cells (Fig. 1). There was no reaction between the antibody and components of the pre-lysozyme treated SDS extracts. A strong reaction, however, was observed between the antibody and the polysaccharide component of the post-lysozyme treated SDS extract corresponding to FBP. A weak background smear was observed surrounding the major FBP band on the nitrocellulose. The antibody was thus regarded as being specific for the FBP complex and used in the reported studies.

ELISA. The wells of microtitre plates (Dynateck) were coated with poly-L-lysine by incubation with $0 \cdot 1 \%(\mathrm{w} / \mathrm{v})$ poly-L-lysine in sodium carbonate buffer, pH $9.6\left[1.59 \mathrm{~g} \mathrm{Na}_{2} \mathrm{CO}_{3}, 2.93 \mathrm{~g} \mathrm{NaHCO}\left(1^{-1}\right)\right]$ for $2 \mathrm{~h}$ at $37^{\circ} \mathrm{C}$. Rhizobium cells $\left(50 \mu \mathrm{l}\right.$ of a suspension containing $2 \times 10^{9}$ cells $\left.\mathrm{ml}^{-1}\right)$ were added to each well and the plates centrifuged for $10 \mathrm{~min}$ at $1000 \mathrm{~g}$. The plates were incubated for $2 \mathrm{~h}$ at $4{ }^{\circ} \mathrm{C}$ and recentrifuged. They were immersed in $0.25 \%(\mathrm{v} / \mathrm{v})$ glutaraldehyde in PBS at $0{ }^{\circ} \mathrm{C}$ for $5 \mathrm{~min}$, washed six times with PBS and blocked with sodium carbonate buffer, pH 9.6, containing $1 \%(\mathrm{w} / \mathrm{v}) \mathrm{BSA}$ and $100 \mathrm{~mm}$-glycine. Antibody to the Rhizobium polysaccharide (FBP) in dilution buffer (PBS containing $0.5 \%, v / v$, Tween 20 and $1 \%, w / v, B S A$ ), was then added to the wells and the plates were incubated at $37^{\circ} \mathrm{C}$ for $2 \mathrm{~h}$. The plates were washed six times with wash buffer (PBS containing $0 \cdot 1 \%, \mathrm{v} / \mathrm{v}$, Tween 20 ) and flicked dry. Peroxidase-labelled goat anti-(rabbit IgG) in dilution buffer was 

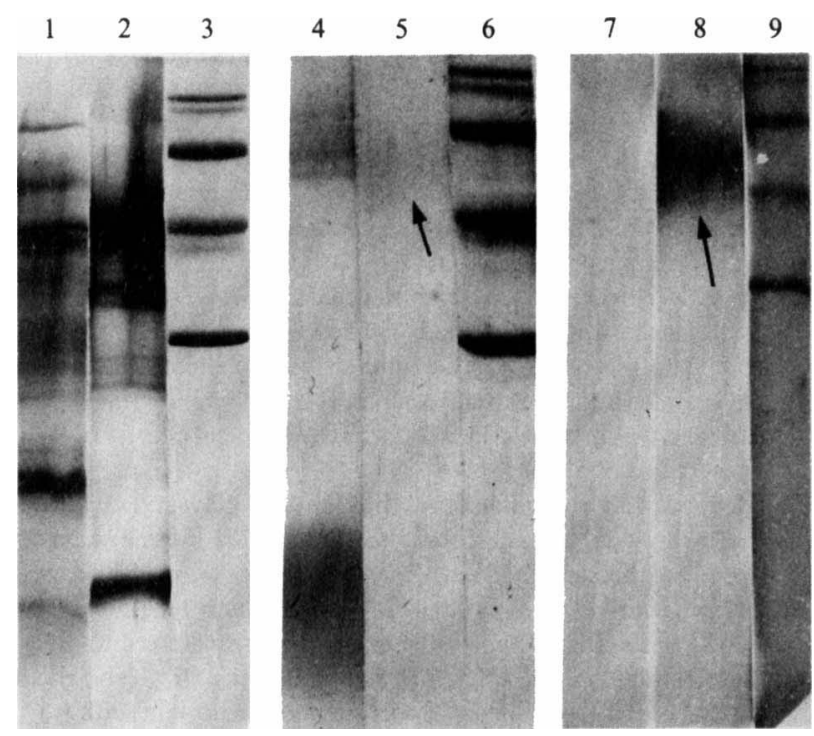

Fig. 1. Testing of specificity of antibodies to FBP by Western blotting. Samples were separated on $15 \%$ (w/v) SDS polyacrylamide gels according to Laemmli (1970) and stained either for protein and polysaccharide or transferred to nitrocellulose (Towbin et al., 1979). Antibodies were detected with phosphatase-labelled antirabbit IgG and napthol AS-MX phosphate and Fast violet B. Arrows $(\rightarrow)$ indicate the position of FBP. Lanes 1-6 are polyacrylamide gels, lanes 7-9 are nitrocellulose after Western blotting. Lanes 1, 4 and 7 are pre-lysozyme SDS extracts of NZP2037 stained for protein, polysaccharide or probed with rabbit anti-FBP antibodies respectively; lanes 2, 5 and 8 are postlysozyme SDS extracts of NZP2037 stained for protein, polysaccharide or probed with rabbit anti-FBP antibodies respectively. Lanes 3, 6 and 9 are $M_{\mathrm{r}}$ marker proteins (from top to bottom): $\beta$-galactosidase, 116000 ; phosphatase b, 97400; BSA, 66000; egg albumin, 45000; and carbonic anhydrase, 29000. Lanes 3 and 6 were stained with Coomassie blue and lane 9 with Amido black.

added to each well and the plates were incubated for a further $1 \mathrm{~h}$ at $37^{\circ} \mathrm{C}$. After six washings with wash buffer, $200 \mu \mathrm{l}$ of substrate [ $40 \mathrm{mg} O$-phenylenediamine and $30 \mu \mathrm{l} \mathrm{H}_{2} \mathrm{O}_{2},(30 \%, \mathrm{v} / \mathrm{v})$ in $100 \mathrm{ml}$ phosphate/citrate buffer, $\mathrm{pH} 6.0\left(7.3 \mathrm{~g} \mathrm{Na}_{2} \mathrm{HPO}_{4} \mathrm{l}^{-1}, 5.1 \mathrm{~g}\right.$ citric acid $\left.\left.\mathrm{l}^{-1}\right)\right]$ was added to each well and the plates were incubated for $30 \mathrm{~min}$ at $20^{\circ} \mathrm{C}$ in the dark. Peroxidase was inactivated by addition of $50 \mu \mathrm{l} 4 \mathrm{M}-\mathrm{H}_{2} \mathrm{SO}_{4}$ to each well. The optical density (at $495 \mathrm{~nm}$ ) of the wells was then recorded with an automatic plate reader (Flow Multiscan MC).

Immunogold staining of Rhizobium cells and bacteroids. Samples of $R$. loti cells (harvested at different stages of growth) and $L$. pedunculatus root nodules formed by $R$. loti strain NZP2037, were prepared and processed for electron microscopy in Lowicryl $\mathrm{K} 4 \mathrm{M}$ resin using the low temperature procedures described by Robertson $e t$ al. (1984). Thin sections were cut with a diamond knife and processed as follows for immunogold staining on 200 mesh gold grids bearing a carbon-Parlodion film. The sections were immersed in anti-FBP antibody $\left(20 \mu \mathrm{g} \mathrm{ml}^{-1}\right.$ in solution $\mathrm{A}: 10 \mathrm{~mm}$-Tris $/ \mathrm{HCl}, \mathrm{pH} 7.5 ; 0.8 \%, \mathrm{w} / \mathrm{v}, \mathrm{NaCl} ; 2 \%, \mathrm{w} / \mathrm{v}, \mathrm{BSA} ; 1 \%, \mathrm{v} / \mathrm{v}$, Tween 20 ) for $1 \mathrm{~h}$ at $37^{\circ} \mathrm{C}$, washed three times with solution A, without BSA, at room temperature, immersed in goat anti-rabbit IgG-Au (20) (Janssen), diluted $1: 10$ with solution $A$ for $1 \mathrm{~h}$ at $37^{\circ} \mathrm{C}$, washed five times with $10 \mathrm{mM}-\mathrm{Tris} / \mathrm{HCl}, \mathrm{pH} 7.5$, containing $0.8 \%(\mathrm{w} / \mathrm{v}) \mathrm{NaCl}$ at room temperature and finally washed with distilled water. The sections were poststained with saturated uranyl acetate for $2 \mathrm{~min}$, followed by lead citrate for $2 \mathrm{~min}$ and viewed in a Phillips EM200 electron microscope.

\section{RESULTS}

\section{Flavolan-binding components of NZP2037 and NZP2213 cells}

Extraction of intact flavolan-treated NZP2037 and NZP2213 cells with SDS removed $70 \%$ of the bound flavolan from NZP2213 cells but none from the NZP2037 cells. As this extraction would have removed most cell components (proteins, polysaccharides) not covalently linked to the peptidoglycan layer of the bacterial cell walls (Braun, 1975) we concluded that the component of NZP2037 cells reacting with flavolan was covalently linked to the peptidoglycan layer. This result also indicated that the component on the surface of the NZP2213 cells reacting 
with the flavolan must be different to that binding flavolan on the NZP2037 cell surface. Gel electrophoresis of the proteins removed from the flavolan-treated cells during this extraction gave patterns identical to those of control (untreated) cells similarly extracted (data not shown).

The Rhizobium cell envelope 'ghosts' remaining after the first round of SDS extraction were then treated with lysozyme and subjected to a second round of SDS extraction. This treatment removed $77 \%$ of the flavolan bound to the NZP2037 cells and a further $9 \%$ from the NZP2213 cells. When these SDS extracts were compared by gel electrophoresis with similar extracts from control cells, two major and one minor component present in the control cell extract were either present in diminished quantity or absent from the flavolan-treated cell extract. Two components (one major, one minor), both proteins, were present in reduced amounts in the extracts of flavolan-treated cells of both strains (Fig. $2 a$ ). These proteins reacted positively with Sudan black (Fig. 2c) suggesting that they were lipoproteins. The second major component, a polysaccharide, was present in NZP2037 cell extracts but was absent from NZP2213 (Fig. 2b) extracts and from extracts of NZP2037 pretreated with flavolan (Fig. $2 d$ ). A new high $M_{\mathrm{r}}$ polysaccharide, associated with flavolan (Fig. 2d), was observed at the top of the separating gel in extracts of NZP2037 cells pretreated with flavolan.

The insoluble residue remaining after the second round of SDS extraction, which still contained about $20 \%$ of the flavolan originally bound to the intact cells of both NZP2037 and NZP2213, was not further analysed.

\section{Partial characterization of the flavolan-binding lipoprotein and polysaccharide}

The $M_{\mathrm{r}}$ values of the two flavolan-binding protein components, thought to be lipoprotein as they both stained positively with Sudan black (Fig. $2 c$ ), were estimated by SDS-PAGE to be 88000 and 44000 . The higher $M_{\mathrm{r}}$ protein may possibly be a covalently linked dimer of the 44000 unit. Exclusion chromatography on Ultragel ACA22 (LKB) in $1 \%$ SDS gave $M_{\mathrm{r}}$ values of 90000 and 45000 for these two proteins, in close agreement with the results from the SDS gels.

The polysaccharide isolated from phenol/water extraction of lysozyme treated NZP2037 cell envelope 'ghosts' was a water-soluble product. It appeared as a poly-dispersed material on polyacrylamide gels (Fig. $2 b$ ) and was found by gel exclusion chromatography to have an approximate average $M_{\mathrm{r}}$ of 55000 .

\section{Binding of flavolan to the NZP2037 FBP}

The ability of the FBP extracted from exponential-phase cells of NZP2037 to bind $L$. pedunculatus root flavolan is shown in Fig. 3. Purified FBP bound up to four times its weight of flavolan. Assuming an $M_{\mathrm{r}}$ of 55000 for FBP and 7000 for the flavolan (Jones et al., 1976), this binding represents a molar ratio of flavolan :FBP of $28: 1$. Flavolan did not bind to extracellular polysaccharide extracted from NZP2037 (Pankhurst et al., 1982) (data not shown).

\section{Presence of FBP in NZP2037 cells at different stages of growth}

Pankhurst et al. (1982) showed that exponential-phase (24 h) cells of NZP2037 were more resistant to $L$. pedunculatus flavolan and able to bind three times more flavolan than exponentialphase cells of NZP2213. In contrast, stationary-phase cells of both strains were equally sensitive to the flavolan. To examine what relationship these observations had to the FBP found on NZP2037 cells, samples of cells were removed from an actively growing $\mathbf{M}^{-}$broth culture of NZP2037 and assayed for the presence of this polysaccharide. It was found that FBP could be extracted from cells only when they were in the exponential-phase of growth (Fig. 4). Cells in early stationary-phase $(48 \mathrm{~h})$ and stationary-phase $(72 \mathrm{~h})$ yielded no extractable FBP. Cells of NZP2213 removed at various times during growth in $\mathbf{M}^{-}$medium contained no extractable FBP. In contrast, the amount of lipoprotein present in SDS extracts of either NZP2037 (Fig. 4) or NZP2213 (data not shown) closely followed the growth curve.

Results of ELISA in which a polyclonal antibody raised against purified FBP (and shown to be specific for this component on NZP2037 cells; see Methods) was reacted with NZP2037 and NZP2213 cells at various stages of growth are presented in Fig. 5. FBP was not detected by ELISA on NZP2213 cells at any stage of growth. In contrast, NZP2037 reacted with the FBP 
(a)

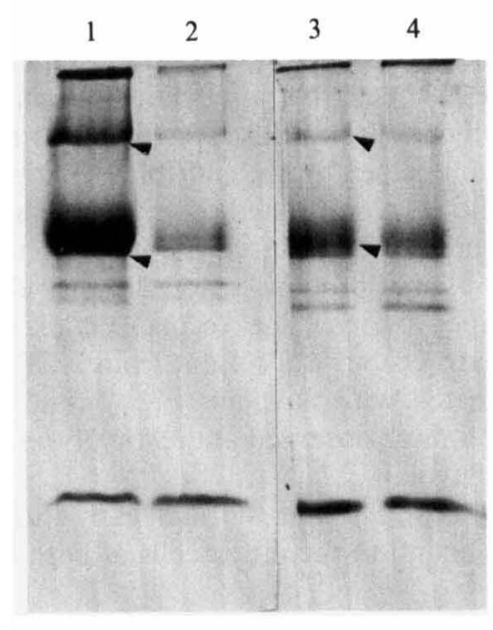

(c)

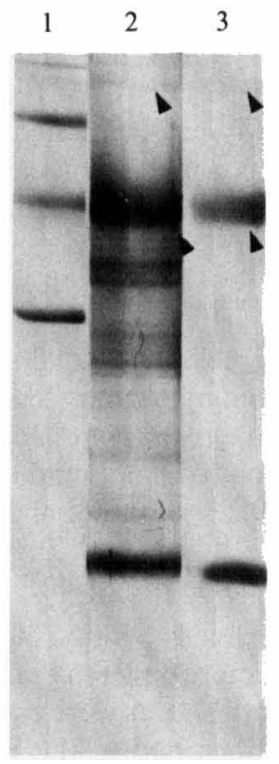

(b)

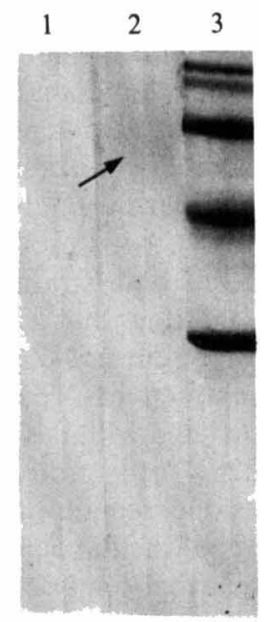

(d)

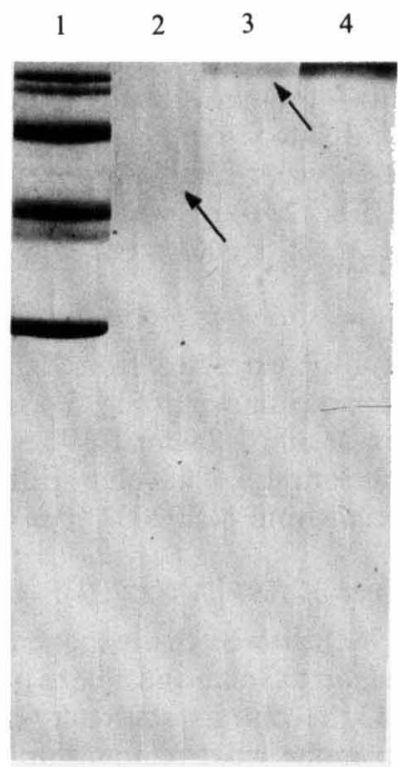

Fig. 2. Polyacrylamide gels of SDS extracts of NZP2037 and NZP2213 cell envelope 'ghosts' after lysozyme treatment. Arrows indicate proteins $(\rightarrow)$ and polysaccharides $(\rightarrow$ ) aggregated by reaction with flavolans. $M_{\mathrm{r}}$ markers were as in Fig. 1. (a) Lane 1, extracts of NZP2037 control; lane 2, NZP2037 cells pretreated with flavolan; lane 3, extract of NZP2213 control; lane 4, NZP2213 cells pretreated with flavolan. (b) Lane 1, NZP2213 extract stained for polysaccharide; lane 2, NZP2037 extract stained for polysaccharide; lane 3, $M_{\mathrm{r}}$ marker proteins. After staining gels were equilibrated in $7 \%$ acetic acid. (c) Lane 1, $M_{\mathrm{r}}$ markers; lane 2 NZP2037 cells extract stained for protein; lane 3, as lane 2 but stained for lipid. (d) Lane 1, $M_{\mathrm{r}}$ markers; lane 2, extract of NZP2037 control cells, and gel stained for polysaccharide; lane 3, extract of NZP2037 cells pretreated with flavolan and the gel stained for polysaccharide; lane 4 , as lane 3 but gel stained for flavolan with vanillin/ $\mathrm{HCl}$. 


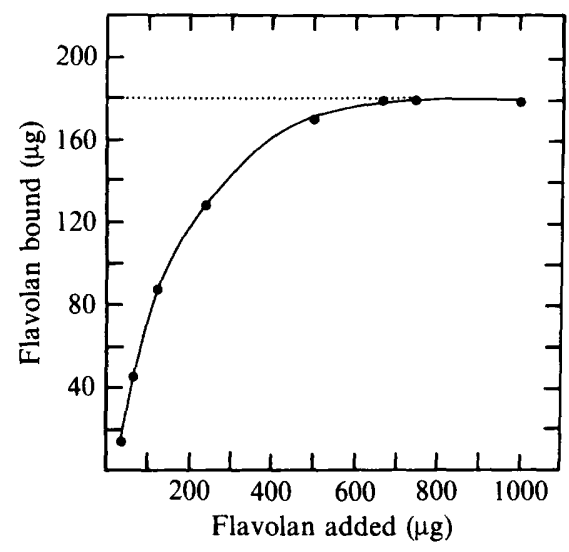

Fig. 3. Binding of $L$. pedunculatus root flavolan to NZP2037 FBP. The dotted line indicates the maximum flavolan bound per $50 \mu \mathrm{g}$ of added FBP.

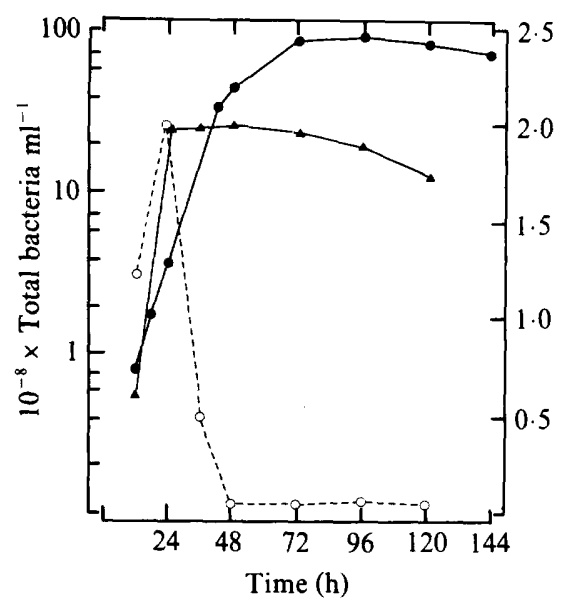

Fig. 4

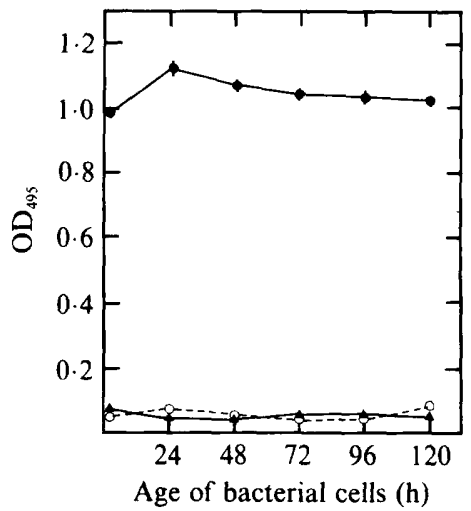

Fig. 5

Fig. 4. Growth (O), lipoprotein content $(\boldsymbol{\Lambda})$ and FBP content $(O)$ of $R$. loti strain NZP2037. Lipoprotein and FBP content were determined after SDS and lysozyme treatment of a standard number $\left(5 \times 10^{9}\right)$ of cells and gel electrophoresis as described in Methods. The optical density values are arbitrary units only.

Fig. 5. ELISA of NZP2037 (O) and NZP2213 (O) bacteria $\left(10^{8}\right.$ cells per sample well) with anti(NZP2037 FBP) antibody and preimmune antisera (A). The FBP and preimmune antibodies were used at $1 / 800$ dilution and the peroxidase anti-(rabbit $\operatorname{IgG}$ ) antibodies at $1 / 2000$ dilution. Optical density was measured at $495 \mathrm{~nm}$. Bars represent the range of four determinations.

antibody at all stages of growth. Exponential-phase cells $(24 \mathrm{~h})$ of NZP2037 showed a small but reproducible increase (about $10 \%$ ) in the amount of antibody bound relative to cells in the other phases of growth (Fig. 5).

\section{Immunogold staining of FBP}

Thin sections of NZP2037 exponential- and stationary-phase cells and NZP2213 exponentialphase cells stained with the FBP antibody and the secondary goat anti-rabbit IgG-Au (20) antibody are shown in Fig. 6. Extensive gold staining is centred over the cell-wall/cellmembrane complex of NZP2037 exponential-phase cells but absent from NZP2213 cells. 

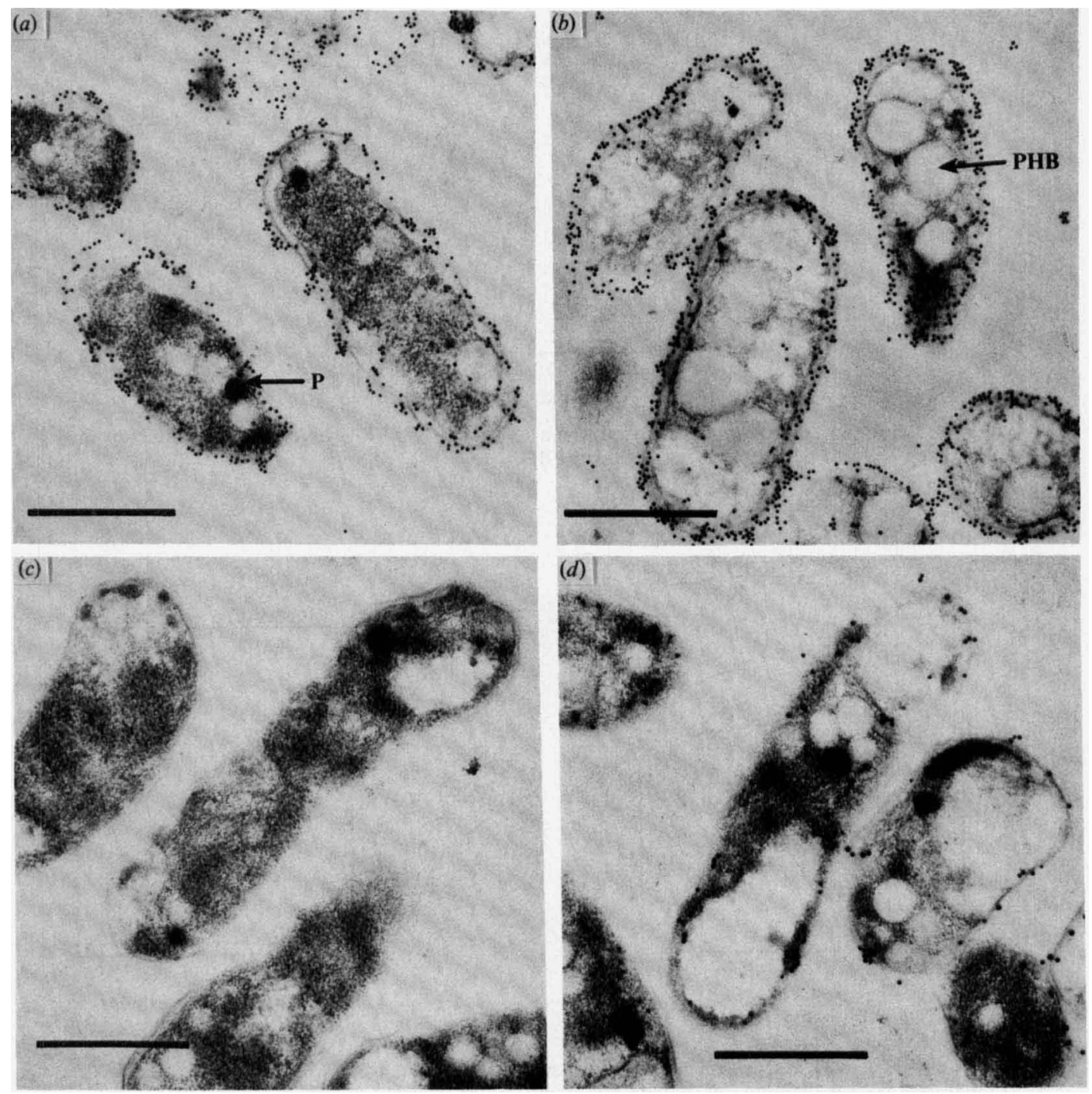

Fig. 6. Immunogold staining for FBP of thin sections of (a) NZP2037 exponential-phase cells, (b) NZP2037 stationary-phase cells, (c) NZP2213 exponential-phase cells and (d) PN236 exponentialphase cells. The anti-FBP antibody was used at a concentration of $20 \mu \mathrm{g} \mathrm{ml}^{-1}$. PHB, poly- $\beta$ hydroxybutyrate; $P$, polyphosphate. Bars, $1 \mu \mathrm{m}$.

NZP2037 stationary-phase cells exhibited a level of staining equivalent to that of NZP2037 exponential-phase cells (Fig. $6 a$ cf. Fig. 6 c) but exponential-phase cells of PN236, a Nod ${ }^{+}$Fix $^{-}$ mutant of NZP2037 (Chua et al., 1985) showed a greatly reduced level of staining. Bacteroids of NZP2037 present in a 6-week-old $L$. pedunculatus root nodule also showed extensive staining over the cell-wall/cell-membrane region (Fig. 7). In addition, significant staining was observed within the peribacteroid space (surrounding the bacteroids) (Fig. 7).

\section{Protection of NZP2213 cells from favolan by addition of NZP2037 FBP}

If the FBP from exponentially growing NZP2037 cells was primarily responsible for enabling NZP2037 to tolerate higher concentrations of flavolan 'in vitro', it might be expected that addition of this material to a suspension of NZP2213 cells would protect them from the 

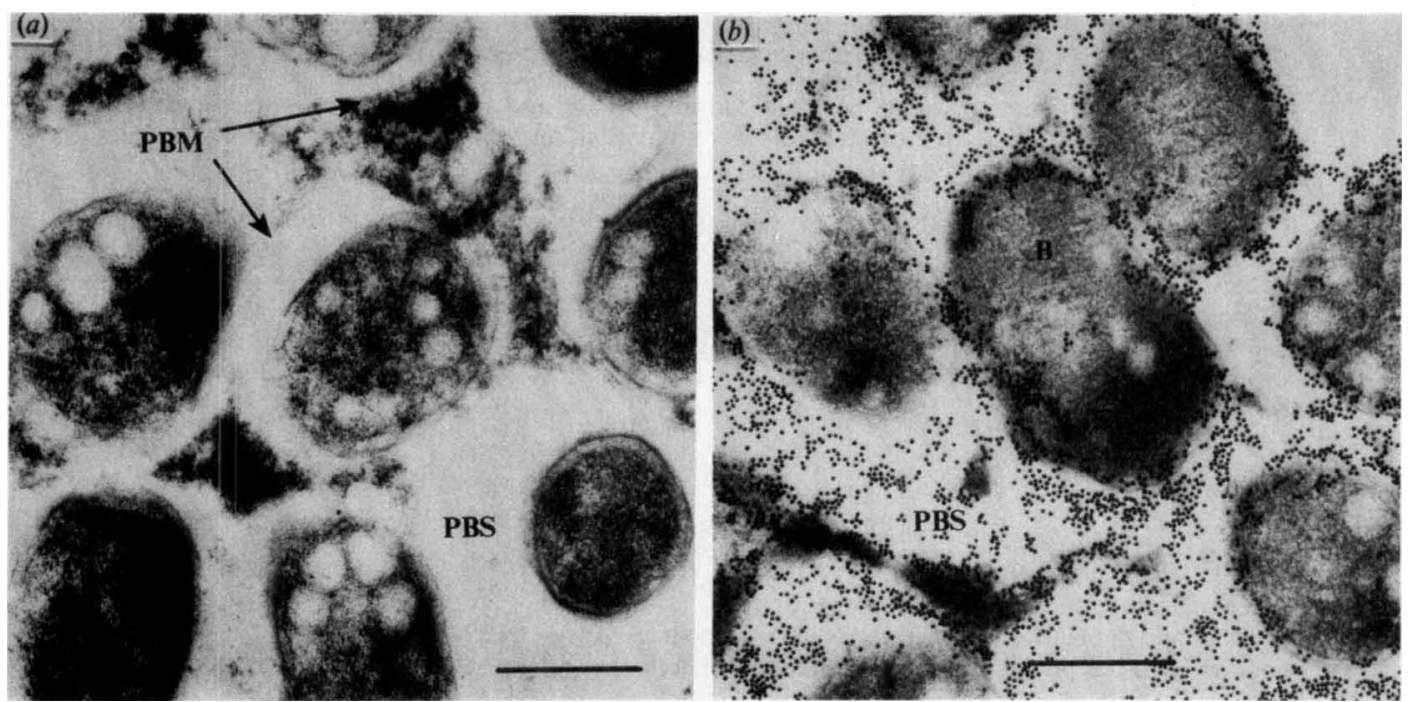

Fig. 7. Immunogold staining for FBP of thin sections of 21-day-old L.pedunculatus root nodules formed by NZP2037. (a) Unstained, control section; (b) section stained with anti-FBP antibody $\left(20 \mu \mathrm{g} \mathrm{ml}^{-1}\right)$. The NZP2037 bacteroids (B) are individually enclosed within a peribacteroid membrane (PBM). The space between the bacteroid and the peribacteroid membrane is called the peribacteroid space (PBS). Bars, $1 \mu \mathrm{m}$.

Table 1. Effect of the addition of NZP2037 FBP on the viability of NZP2037 and NZP2213 cells grown in the presence of $L$. pedunculatus root flavolan

The number of viable cells was determined $24 \mathrm{~h}$ after addition of flavolan and/or FBP to a suspension containing $1.6 \times 10^{5} \mathrm{cells} \mathrm{m}^{-1}(\mathrm{NZP2213})$ and $2.1 \times 10^{5} \mathrm{cells} \mathrm{ml}^{-1}$ (NZP2037). The final flavolan concn was $50 \mu \mathrm{g} \mathrm{ml}^{-1}$. Each value is the mean of four determinations. ND, Not determined.

\begin{tabular}{|c|c|c|}
\hline \multirow[b]{2}{*}{ Treatment } & \multicolumn{2}{|c|}{$\begin{array}{l}\text { Total number of } \\
\text { viable cells } \mathrm{ml}^{-1}\end{array}$} \\
\hline & NZP2213 & NZP2037 \\
\hline Control & $5.2 \times 10^{6}$ & $7.6 \times 10^{6}$ \\
\hline Flavolan & 0.0 & $5.4 \times 10^{6}$ \\
\hline Flavolan + FBP $\left(50 \mu \mathrm{g} \mathrm{ml}^{-1}\right)$ & $8.2 \times 10^{3}$ & ND \\
\hline Flavolan + FBP $\left(100 \mu \mathrm{g} \mathrm{ml}^{-1}\right)$ & $1.8 \times 10^{6}$ & ND \\
\hline Flavolan + FBP $\left(200 \mu \mathrm{g} \mathrm{ml}^{-1}\right)$ & $2 \cdot 1 \times 10^{6}$ & $5.6 \times 10^{6}$ \\
\hline
\end{tabular}

bactericidal effect of the flavolan. To test this hypothesis NZP2037 FBP $\left(50,100\right.$ or $200 \mu \mathrm{g} \mathrm{ml}^{-1}$ final concn) was added to a suspension of washed NZP2213 cells $\left(10^{5}\right.$ cells $\left.\mathrm{ml}^{-1}\right)$ in $\mathrm{M}^{-}$broth. Flavolan $\left(50 \mu \mathrm{g} \mathrm{ml}^{-1}\right.$ final concn) was added and the mixture incubated with shaking $\left(100\right.$ r.p.m.) at $28^{\circ} \mathrm{C}$. After $24 \mathrm{~h}$ incubation the total number of viable cells in each mixture was determined by dilution plating onto $\mathrm{M}^{+}$medium: $50 \mu \mathrm{g}$ flavolan $\mathrm{ml}^{-1}$ completely killed NZP2213 cells but had little effect on NZP2037 cells (Table 1). However, addition of NZP2037 FBP (100-200 $\mu \mathrm{g} \mathrm{ml}^{-1}$ final concn) to NZP2213 cell suspensions gave significant protection against the flavolan (Table 1). 
Table 2. Effect of inoculation of L. pedunculatus with NZP2037/NZP2213 mixtures on plant growth and strain occupancy of individual nodules

A spectinomycin-resistant mutant of NZP2037 (strain PN4001) and a streptomycin-resistant mutant of NZP2213 (strain PN4115) were used. Plants were harvested and the contents of individual nodules examined 6 weeks after inoculation.

\begin{tabular}{|c|c|}
\hline \multicolumn{2}{|c|}{$\begin{array}{c}\text { No. of } \\
\text { bacteria } \\
\text { added per plant* }\end{array}$} \\
\hline PN4001 & PN4115 \\
\hline $10^{2}$ & $10^{6}$ \\
\hline $10^{4}$ & $10^{6}$ \\
\hline $10^{6}$ & $10^{6}$ \\
\hline $10^{6}$ & $10^{4}$ \\
\hline
\end{tabular}

Uninoculated

$\begin{array}{ccc}\begin{array}{c}\text { Shoot } \\ \text { dry wt } \\ \text { (mg per plant) }\end{array} & \begin{array}{c}\text { No. of } \\ \text { nodules per } \\ \text { plant }\end{array} & \begin{array}{c}\text { No. of } \\ \text { nodules } \\ \text { tested }\end{array} \\ 1.2 & 11 & 30 \\ 2.2 & 12 & 30 \\ 4.7 & 10 & 30 \\ 4.5 & 13 & 30 \\ 1.1 & - & -\end{array}$

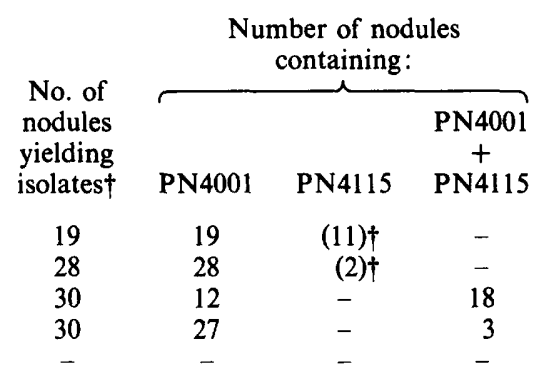

* Average number for six individual plants.

$\dagger$ Bacteria could not be isolated from the $\mathrm{Nod}^{+} \mathrm{Fix}^{-}$nodules formed by PN4115 following surface sterilization. Such nodules were morphologically tumour-like and therefore assumed to be formed by PN4115.

\section{Role of FBP in nodulation}

If the presence of FBP on NZP2037 cells and its absence on NZP2213 cells was in any way correlated with the $\mathrm{Nod}^{+} \mathrm{Fix}^{+}$phenotype of NZP2037 and the $\mathrm{Nod}^{+} \mathrm{Fix}^{-}$phenotype of NZP2213 on L. pedunculatus (Pankhurst \& Jones, 1979) it might be expected that addition of FBP to L. pedunculatus inoculated with NZP2213 may alter the nodule phenotype of this strain for this host. To test this possibility FBP was added to the nutrient solution bathing the roots of individual L. pedunculatus seedlings at the time of inoculation with NZP2213. The number of NZP2213 bacteria added per plant was initially low (about $10^{3}$ bacteria per plant) and FBP was added in quantities ranging from $100-1500 \mu \mathrm{g}$ per plant. No change to the $\mathrm{Nod}^{+} \mathrm{Fix}^{-}$ phenotype of NZP2213 was observed. However, after 6 weeks the tumour-like structures formed by NZP 2213 on $L$. pedunculatus were noticeably larger on plants treated with FBP than on control untreated plants.

In another experiment $L$. pedunculatus seedlings were 'co-inoculated' with a bacterial suspension containing antibiotic-resistant mutants of NZP2037 and NZP2213 in different ratios. This was done to see if the continued production of FBP by NZP2037 could assist NZP221 3 into a Nod ${ }^{+} \mathrm{Fix}^{+}$nodule on this host. $\mathrm{Nod}^{+} \mathrm{Fix}^{+}$nodules containing both strains were readily obtained but only when a high (about $10^{6}$ bacteria per plant) number of both strains was initially added to the plants (Table 2). Lowering the number of bacteria of one strain relative to the other resulted in the formation of nodules containing only NZP2037 or tumour-like structures (presumably formed by NZP2213) from which no bacteria could be isolated after surface sterilization (Table 2).

\section{DISCUSSION}

The principal result of this study was the demonstration that resistance of $R$. loti strain NZP2037 to the prodelphinidin-rich flavolan from $L$. pedunculatus was associated with the presence of a strain-specific polysaccharide component in the outer cell membrane complex of this bacterium. $R$. loti strain NZP2213, which is sensitive to this flavolan, did not contain this polysaccharide component in its outer cell membrane.

With NZP2037, stepwise extraction of flavolan-treated exponential-phase cells with SDS, and SDS after lysozyme treatment, showed that all the flavolan was tightly bound to the cells and released only after lysozyme treatment. Approximately $70 \%$ of the flavolan was bound to a specific polysaccharide (termed the FBP), $10 \%$ to lipoprotein and $20 \%$ to further unidentified 
components. In contrast, about $70 \%$ of the flavolan bound to NZP2213 cells was released by the initial SDS extraction. The remaining $30 \%$ was, as in NZP2037, bound to lipoprotein $(10 \%)$ and unidentified components $(20 \%)$. These results suggest that the outer surfaces of exponentially growing NZP2037 and NZP2213 cells are different, and that whereas with NZP2213 the bulk of the flavolan binds to components (polysaccharides, proteins) essential for cell viability the bulk of the flavolan molecules bind to FBP (a component apparently not essential for cell viability) on the NZP2037 cell surface. This 'preferential binding' of flavolan to FBP on the surface of exponentially growing NZP2037 cells correlates with the ability of these cells to remain viable in the presence of flavolan (Pankhurst et al., 1982).

The apparent growth-phase-dependent nature of flavolan-resistance shown by NZP2037 cells (Pankhurst et al., 1982) correlated with our ability to extract FBP from the cells. Resistance and concentration of extractable FBP were both highest in cells in the exponential-phase of growth (Pankhurst et al., 1982; Fig. 4). Stationary-phase cells of NZP2037, which are as sensitive to the flavolan as NZP2213 cells (Pankhurst et al., 1982), contained no extractable FBP (Fig. 4). This change in ability to extract FBP from NZP2037 cells as they progress from exponential- to stationary-phase growth is of interest and suggests that major changes occur to the surface characteristics of NZP2037 cells as they age. Changes to the lipopolysaccharide and capsular polysaccharide components of $\boldsymbol{R}$. trifolii and Bradyrhizobium japonicum cells that bind clover and soybean seed lectins respectively have been reported as these bacteria progress through the growth cycle (Hrabak et al., 1981; Bhuvaneswari et al., 1977). A decline in lectin-binding activity of $\boldsymbol{B}$. japonicum cells as they enter stationary-phase coincides with methylation of the galactose residues reducing the ability of the polysaccharide to bind the lectin (Mort $\&$ Bauer, 1980).

ELISA and immunogold staining of intact NZP2037 and NZP2213 cells with a polyclonal antibody specific for FBP confirmed the presence of FBP on the surface of NZP2037 cells and its absence from NZP2213 cells. In addition, both of these experiments demonstrated the presence of anti-FBP determinants on NZP2037 stationary-phase cells (Figs 5 and 6) whereas FBP could not be extracted from cells in stationary-phase (Fig. 4). A possible explanation for this is that FBP moieties become increasingly cross-linked as the NZP2037 cells progress from exponential- to stationary-phase growth. This cross-linking could reduce the flavolan-binding capacity of the FBP and make it refractory to extraction, but it may not alter its capacity to bind to the FBP antibody. The antibody, because it is polyclonal, is likely to bind to many sites on FBP that are not specifically involved in binding flavolan.

The experiments involving the immunogold staining of exponential-phase cells of the Tn5induced mutant of NZP2037, strain PN236, and of NZP2037 bacteroids, were both of potential significance. Strain PN236 is similar to NZP2213 in that it forms tumour-like, bacteria-free structures rather than true nodules on L. pedunculatus (Chua et al., 1985). This strain has a level of resistance to the $L$. pedunculatus flavolan in vitro that is approximately 3-fold lower than that of NZP2037, i.e. approximating that of the flavolan-sensitive strain NZP2213 (C. E. Pankhurst, unpublished results) and, as shown in Fig. 6(d), it appears to have a reduced amount of FBP in its outer cell membrane. This result provides further evidence linking the presence of FBP to flavolan-resistance and flavolan-resistance to ability to develop normal nodules; it also further demonstrates the specificity of the anti-FBP antibody. In direct contrast to the reduced staining of PN236 cells with anti-FBP, NZP2037 bacteroids showed a strong reaction (Fig. 7). Of interest was the occurrence of anti-FBP components in the peribacteroid space. This is possibly a consequence of the pronounced changes that occur to the Rhizobium cell membrane complex during bacteroid development. Included in this differentiation process is the potential sloughing-off of the outer cell membrane (Bal et al., 1980), which could result in the release of FBP into the peribacteroid space.

The observation that FBP was only released from exponential-phase cells of NZP2037 following lysozyme treatment of cell envelope ghosts suggests that it is covalently linked to the peptidoglycan layer or gel (Hobot et al., 1985) separating the outer and inner cell membrane. Similarly, the lipoprotein that bound to flavolan is also probably covalently linked to the peptidoglycan. As the FBP has not been characterized beyond an approximate $M_{\mathrm{r}}$ of 55000 it is 
not known what particular characteristic affords it the capacity to effectively bind flavolan both in vivo and in vitro (Fig. 3). However, as both NZP2037 and NZP2213 are resistant to procyanidin-rich flavolans (Pankhurst \& Jones, 1979), and as procyanidin differs from prodelphinidin only with respect to carrying two rather than three hydroxyl groups on the B ring of the molecule (Jones et al., 1976), there must be some specificity between FBP and the trihydroxy groups of the B ring of prodelphinidin.

The biological efficacy of the NZP2037 FBP was demonstrated by its capacity to afford a concentration-dependent protection of NZP2213 cells to the bactericidal effect of the $L$. pedunculatus flavolan (Table 2). However, addition of FBP to $L$. pedunculatus seedlings inoculated with NZP2213 did not alter the Nod+Fix- phenotype of NZP2213 for this host. While it may have been expected that if sensitivity of NZP2213 to the L.pedunculatus flavolan is the reason for its failure to infect the roots of this plant (Pankhurst \& Jones, 1979), and that the presence of FBP in the growth medium could therefore assist in overcoming this, it is likely that any interaction between NZP2213 cells and flavolan that will have a direct effect on the outcome of the symbiosis will occur at the site of infection and/or during the infection process itself. The presence of FBP in the growth medium is therefore unlikely to prevent this. However, the presence of NZP2037 rhizobia in the rhizosphere along with NZP2213 did permit NZP2213 rhizobia to gain entry into a L. pedunculatus nodule (Table 2). Such 'picka-back' entry of a noninvasive Rhizobium strain in the presence of an invasive strain has been reported by Rolfe $e t$ al. (1980). With NZP2037 and NZP2213 dual occupancy of nodules depended on equal numbers of both rhizobia being present in the inoculum. It could be argued that the continued production of FBP by live NZP2037 rhizobia was responsible for the entry of NZP2213 into the $L$. pedunculatus nodule.

The $\mathrm{Nod}^{+} \mathrm{Fix}^{-}$nodules formed by NZP2213 and PN236 on L. pedunculatus are tumour-like and contain no intracellular rhizobia (Pankhurst et al., 1979; Chua et al., 1985). Similar structures, containing no intracellular rhizobia, have since been described for mutants of $R$. meliloti (Finan et al., 1985) and $R$. phaseoli (Vandenbosch et al., 1985) deficient in exopolysaccharides, and for transconjugants of Agrobacterium tumefaciens and Escherichia coli containing the $R$. meliloti symbiotic plasmid or regions of it carrying nodulation genes (Wong $e t$ al., 1983; Truchet et al., 1984; Hirsch et al., 1985). In all cases it appears that while certain nodulation genes, e.g. the 'common' NodABCD genes (Egelhoff \& Long, 1985), are being expressed by these bacteria in association with the legume root thus producing a 'nodule-like' or 'tumour-like' structure, genes coding for essential steps in the infection process per se are either absent or non-functional. With $R$. loti strain NZP2213 it may be suggested that it is its sensitivity to the flavolan present in L. pedunculatus roots that blocks its entry into the root cells of this Lotus species, but that as a consequence of other nodulation genes becoming activated a 'tumour-like' structure is still developed.

We wish to thank Raymond Bennett for photography and Richard Broadhurst for assistance in producing the FBP antibody.

\section{REFERENCES}

Bal, A. K., Shantharam, S. \& Verma, D. P. S. (1980). Changes in the outer cell wall of Rhizobium during development of root nodule symbiosis in soybean. Canadian Journal of Microbiology 26, 1096-1103.

Bhuvaneswari, T. V., Pueppke, S. G. \& Bauer, W. D. (1977). Role of lectins in plant-microorganism interactions. I. Binding of soybean lectin to rhizobia. Plant Physiology 60, 486-491.

BRAUN, V. (1975). Covalent lipoprotein from the outer membrane of Escherichia coli. Biochimica et biophysica acta 415, 335-377.

BROADHURST, R. B. \& JoNES, W. T. (1978). Analysis of condensed tannins using acidified vanillin. Journal of the Science of Food and Agriculture 29, 788794.
Chua, K.-Y., Pankhurst, C. E., MacDonald, P. E., HOPCROFT, D. H., JAR VIS, B. D. W. \& SCOTT, D. B. (1985). Isolation and characterization of transposon Tn5-induced symbiotic mutants of Rhizobium loti. Journal of Bacteriology 162, 335-343.

EgELHOFF, T. T. \& LONG, S. R. (1985). Rhizobium meliloti nodulation genes: Identification of nod DABC gene products, purification of nodA protein, and expression of nodA in Rhizobium meliloti. Journal of Bacteriology 164, 591-599.

Finan, T. M., Hirsch, A. M., Leigh, J. A., Johansen, E., Kuldau, G. A., Deegan, S., Walker, G. C. \& SIGNER, E. R. (1985). Symbiotic mutants of Rhizobium meliloti that uncouple plant from bacterial differentiation. Cell 40, 869-877. 
HARBOE, N. \& INGILD, A. (1973). Immunization, isolation of immunoglobulins, estimation of antibody titre. In A Manual of Quantitative Immunoelectrophores's, Methods and Applications, pp. 161-164. Edited by N. H. Axelson, J. Kroll \& B. Weeke. Oslo: Universitetsforlaget.

Hirsch, A. M., Drake, D., Jacobs, T. W. \& LoNG, S. R. (1985). Nodules are induced on alfalfa roots by Agrobacterium tumefaciens and Rhizobium trifolii containing small segments of the Rhizobium meliloti nodulation region. Journal of Bacteriology 161, 223230.

Hobot, J. A., Carlemalm, E., Villiger, W. \& Kellenberger, E. (1984). Periplasmic gel: new concept resulting from the reinvestigation of bacterial cell envelope ultrastructure by new methods. Journal of Bacteriology 160, 143-152.

Hrabak, E. M., Urbano, M. R. \& Dazzo, F. B. (1981). Growth-phase-dependent immunodeterminants of Rhizobium trifolii lipopolysaccharide which bind trifoliin A, a white clover lectin. Journal of Bacteriology 148, 697-711.

Jarvis, B. D. W., Pankhurst, C. E. \& Patel, J. J. (1982). Rhizobium loti, a new species of legume root nodule bacteria. International Journal of Systematic Bacteriology 32, 378-380.

Jones, W. T. \& Mangan, J. L. (1977). Complexes of the condensed tannins of sainfoin (Onobrychis viciifolia Scop.) with fraction 1 leaf protein and with submaxillary mucoprotein, and their reversal by polyethylene glycol and $\mathrm{pH}$. Journal of the Science of Food and Agriculture 28, 126-136.

JoNes, W. T., BROADHURST, R. B. \& LyTtLETON, J. W. (1976). The condensed tannins of pasture legume species. Phytochemistry 15, 1407-1409.

Jones, W. T., BroAdhuRst, R. B. \& GuRnSEy, M. P. (1982). Partial characterization of bovine salivary proteins by electrophoretic methods. Biochimica et biophysica acta 701, 382-388.

LAEMMLI, U. K. (1970). Cleavage of structural proteins during the assembly of the head of bacteriophage T4. Nature, London 227, 680-685.

MORT, A. J. \& BAUER, W. D. (1980). Composition of the capsular and extracellular polysaccharides of Rhizobium japonicum: changes with culture age and correlations with binding of soybean seed lectin to the bacteria. Plant Physiology 66, 158-163.

Pankhurst, C. E. (1977). Symbiotic effectiveness of antibiotic-resistant mutants of fast- and slow-growing strains of Rhizobium nodulating Lotus species. Canadian Journal of Microbiology 23, 1026-1033.

Pankhurst, C. E. (1981). Effect of plant nutrient supply on nodule effectiveness and Rhizobium strain competition for nodulation of Lotus pedunculatus. Plant and Soil 60, 325-339.
Pankhurst, C. E. \& Jones, W. T. (1979). Effectiveness of Lotus root nodules. II. Relationship between root nodule effectiveness and 'in vitro' sensitivity of fast-growing Lotus rhizobia to flavolans. Journal of Experimental Botany 30, 1095-1107.

Pankhurst, C. E., Craig, A. S. \& Jones, W. T. (1979). Effectiveness of Lotus root nodules. I. Morphology and flavolan content of nodules formed on Lotus pedunculatus by fast-growing Lotus rhizobia. Journal of Experimental Botany 30, 1085-1093.

Pankhurst, C. E., Jones, W. T. \& Craig, A. S. (1982). Bactericidal effect of Lotus pedunculatus root flavolan on fast-growing Lotus rhizobia. Journal of General Microbiology 128, 1567-1576.

Rolfe, B. G., Gresshoff, P. M., Shine, J. \& Vincent, J. M. (1980). Interaction between a non-nodulating and an ineffective mutant of Rhizobium trifolit resulting in effective (nitrogen-fixing) nodulation. Applied and Environmental Microbiology 39, 449-452.

Robertson, J. G., Wells, B., Bisseling, T., FARNDEN, K. J. F. \& JohNSTON, A. W. B. (1984). Immunogold localization of leghaemoglobin in cytoplasm in nitrogen-fixing root nodules of pea. Nature, London 311, 254-256.

Towbin, H., Staehelin, T. \& Gordon, J. (1979). Electrophoretic transfer of proteins from polyacrylamide gels to nitrocellulose sheets: procedure and some applications. Proceedings of the National Academy of Sciences of the United States of America 76, 4350-4354.

Truchet, G., Rosenberg, C., Vasse, J., Julliot, J.-S., Camut, S. \& Denaire, J. (1984). Transfer of Rhizobium meliloti pSym genes into Agrobacterium tumefaciens: host-specific nodulation by atypical infection. Journal of Bacteriology 157, 134-142.

Vandenbosch, K. A., Noel, K. D., Kaneko, Y. \& NEWCOMB, E. G. (1985). Nodule initiation elicited by noninfective mutants of Rhizobium phaseoli. Journal of Bacteriology 162, 950-959.

WeSTPHAL, O. \& JANN, K. (1965). Bacterial lipopolysaccharides. Extraction with phenol water and further applications of the procedure. In Methods in Carbohydrate Chemistry, Vol. 5, pp. 83-91. Edited by R. L. Whistler. New York: Academic Press.

Wong, C. H., Pankhurst, C. E., Kondorosi, A. \& BroughtoN, W. J. (1983). Morphology of root nodules and nodule-like structures formed by Rhizobium and Agrobacterium strains containing a Rhizobium meliloti megaplasmid. Journal of Cell Biology 97 , 787-794.

Zacharius, R. M., Zell, T. E., Morrison, J. H. \& WoODLOCK, J. J. (1969). Glycoprotein staining following electrophoresis on acrylamide gels. Analytical Biochemistry 30, 148-152. 